\title{
Teachers' understanding of bullying
}

Faye Mishna, Iolanda Scarcello, Debra Pepler, \& Judith Wiener

Version Published Version/ Final PDF

Citation Mishna, F., et al. (2005) Teachers' understanding of bullying. Canadian

(published version) Journal of Education/Revue canadienne de l'éducation 28(4): 718-738. doi:

$10.2307 / 4126452$.

Always cite the published version, so the author(s) will receive recognition through services that track citation counts, e.g. Scopus. If you need to cite the page number of the TSpace version (original manuscript or accepted manuscript) because you cannot access the published version, then cite the TSpace version in addition to the published version using the permanent URI (handle) found on the record page. 


\title{
Teachers' Understanding of Bullying
}

\author{
Faye Mishna, Iolanda Scarcello, Debra Pepler, \\ $\mathcal{E}$ Judith Wiener
}

Using semi-structured interviews, we examined teachers' understanding of bullying of children in their classes. Although teachers' definitions of bullying included both direct and indirect behaviours, several factors influenced how they characterized and responded to incidents. These factors included whether the teachers viewed an incident as serious or considered a victimized child responsible, whether a child matched their assumptions about victim characteristics and behaviours, and whether they described feeling empathy for a child. The nature of the school environment and organization such as availability of systemic support in addressing bullying incidents were further factors that influenced teachers' awareness and responses.

Key words: peer victimization, qualitative study on bullying, understanding bullying, response to bullying

À l'aide d'entrevues semi-structurées, les auteures ont étudié comment les enseignants perçoivent l'intimidation dans leurs classes. Bien que leurs définitions de l'intimidation comprennent à la fois les comportements directs et indirects, plusieurs facteurs influencent leur façon de caractériser les incidents et d'y réagir, notamment s'ils considèrent que l'incident est sérieux ou que la victime est responsable, si la victime correspond à leurs théories implicites sur les caractéristiques et les comportements d'une victime et s'ils ressentent de l'empathie pour la victime. Le climat de l'école et les structures offertes tel un soutien systémique pour faire face aux incidents d'intimidation faisaient également partie des facteurs ayant une incidence sur la sensibilisation et les réactions des enseignants.

Mots clés: victimisation par des pairs, étude qualitative sur l'intimidation, comprendre l'intimidation, réagir à l'intimidation.

Bullying is reported to be pervasive in many countries around the world (Hazler, Miller, Carney, \& Green, 2001; Olweus, 1994). Both bullies and victims are at risk of developing psychosocial and psychiatric problems that may continue into adulthood (Nansel, Overpeck, Pilla, Ruan,

CANADIAN JOURNAL OF EDUCATION 28, 4 (2005): 718-738 
Simons-Morton, \& Scheidt, 2001; Olweus, 1993).

In this study, we examined teachers' understanding of bullying of those students in their classes who self-identified as victims. Conceptually, this research builds on the assumption that, because people are embedded in social and environmental contexts, multiple factors invariably influence social behavioural patterns (Cairns \& Cairns, 1991; Germain \& Bloom, 1999). Such factors include individual characteristics, social interactions, and cultural and ecological conditions (Cairns \& Cairns, 1991). It follows, according to this ecological systemic framework, that bullying does not reside solely with the child who bullies or who is victimized. Rather, bullying unfolds in the social context of the peer group, the classroom, the school, the family and the larger community. A comprehensive framework therefore, becomes essential to investigate the various elements influencing bullying (Atlas \& Pepler, 1998; Craig \& Pepler, 1997; Craig, Pepler, \& Atlas, 2000; Hanish \& Guerra, 2000; Olweus, 1994).

Although children's decision to disclose is multi-determined, their teachers' response is likely a key factor in choosing to disclose their victimization (Craig \& Pepler, 1996). Students report that teachers do not consistently intervene to stop bullying (Atlas \& Pepler, 1998). One study found that 25 per cent of students indicated that teachers usually intervened, in contrast to 75 per cent of teachers reporting that they usually intervened (Ziegler \& Rosenstein-Manner, 1991). Teachers' explanations for their apparent lack of intervention include uncertainty about how to respond, not having witnessed the incidents, and identification of mild bullying as typical childhood behaviour without serious ramifications (Atlas \& Pepler, 1998; Craig \& Pepler, 1997). Moreover, adults may have difficulty recognizing bullying behaviour because of the complex dynamics involved (Hazler, Carney, Green, Powell, \& Jolly, 1997; Roberts \& Morotti, 2000).

Research is lacking on teachers' understanding of bullying and on factors that influence their views and interventions. Teacher variables must be considered to understand and address bullying. Results of a study considering factors that may influence teachers' ability to identify bullies and victims indicate that teachers' accurate identification of bullies and victims is influenced by a number of factors such as age of 
the students, frequency of contact with the students, and nature of the bullying behaviour (Leff, Kupersmidt, Patterson, \& Power, 1999).

Kallestad and Olweus (2003) found that factors that predict the degree to which teachers implemented the Olweus Bullying Prevention Program included their views on the importance of staff in addressing bullying, the amount of program information they read, their perceptions of the degree of bullying in their classroom, their own experiences of victimization as a child, and their emotional responsiveness and empathy towards children who are bullied. In their study of teachers' views on bullying, Siann, Callaghan, Lockhart, and Rawson (1993) concluded that ambiguity and teachers' own subjective responses to incidents are inherent in bullying. Boulton (1997) conducted a study to elicit teachers' attitudes towards bullying and their beliefs about their ability to deal with bullying. Boulton found that most of the teachers considered physical assaults and threats bullying; however, a significant proportion did not view behaviours such as exclusion or name-calling bullying. Townsend-Wiggins (2001) found that teachers' understanding of bullying, particularly relational bullying, was limited.

Craig, Henderson, and Murphy (2000) examined the effects of contextual factors (e.g., forms of bullying), and characteristics (e.g., gender) of teacher candidates on their attitudes towards bullying and on their interventions. The teacher candidates considered physical aggression more serious and deserving of intervention than verbal aggression or exclusion. They were even less likely to consider verbal aggression and exclusion that they did not witness as bullying or to intervene. The teacher candidates who expressed empathy for others were more likely to identify bullying and to report that they would intervene. Nicolaides, Toda, and Smith (2002) conducted a study on teacher candidates' knowledge and attitudes regarding bullying, their views on the significance of bullying, and their confidence in dealing with bullying. The preservice teachers were informed about the prevalence of bullying but not about other aspects of the phenomenon. The respondents depicted bullies as having low self-esteem and lacking social skills, which contradicts emerging evidence that some bullies actually "may be quite socially skilled-adept manipulators of the social 
environment who can get rewards from bullying more vulnerable peers" (p. 115).

Teachers are influential in students' daily lives, which includes recognizing and responding to bullying incidents and implementing programs. This study adds to the knowledge of this complex phenomenon by focusing on teachers' understanding of bullying and the factors that might influence how they recognize and respond to bullying incidents. Teachers' understanding may well determine whether they see an incident as bullying and whether they intervene appropriately (Boulton, 1997). The adult-child relationship affects children's ability to manage in many areas, and specifically in bullying situations. Integral to the bullying interaction is the victim's inability to defend him or herself and others' obligation to intervene (Atlas \& Pepler, 1998; Olweus, 1991). Scholars have conducted considerably less research on children who are victimized than on children who bully (Bernstein \& Watson, 1997; Prinstein, Boergers, \& Vernberg, 2001). There are few qualitative studies on the experiences of victimized children or their parents or teachers (Borg, 1998; Owens, Shute, \& Slee, 2000). Qualitative research methodology can provide additional insight into more subtle types of bullying and the dynamics of bullying behaviour (Cullingford \& Morrison, 1995; Smith \& Brain, 2000).

\section{METHODOLOGY}

Utilizing basic qualitative methodology (Merriam, 2002), we conducted our research in four urban public schools that were located in communities that differed in such factors as income, family composition, and percentage of recent immigrants (Astor, Meyer, \& Behre, 1999). We categorized one school in the lowest income range and another, in the second lowest. These schools had a high percentage of single parent families, a low proportion of higher education among parents, many families who lived in subsidized housing, and high numbers of recent immigrants. We categorized the third school as in the second highest income level, and the fourth as in the highest income level. These schools had a moderate to low percentage of single parent families, mixed to high education levels, with most families living in single detached housing, and low to moderate recent immigrants (Schools Like Us 
Project Description, 2001-02). As a result, we were able to consider the experiences from a range of socio-economic levels.

We administered a questionnaire ("Safe School Questionnaire," Pepler, Connolly, \& Craig, 1993, adapted from Olweus, 1989) to students in grades four and five in four public schools to identify students who reported being victims of bullying. The focus of our study was the individual interviews with teachers on one occasion about their understanding of bullying and then consideration of their responses in light of their students' identification as victims. Using basic qualitative inquiry, the aim was to gain understanding of how the teachers understood the phenomenon of bullying in general and specifically, with respect to the self-identified students (Merriam, 2002).

The research assistants initiated a classroom discussion on school bullying. We then obtained parental consent to have their children complete a questionnaire, which the research assistants administered with the children's assent. The child and teacher's names were placed on the questionnaire. We used two items from the Safe School questionnaire to assess involvement in bullying: "How often have you been bullied in the current term?" and "How often have you been bullied in the last five days?" On the basis of the questionnaire results, we selected children to provide representation according to gender and grade. Nine boys and nine girls in grades four and five who identified being frequently bullied were selected. We also obtained consent and assent from the parents and children to interview the children's teachers and to inform the teachers that the child had self-identified as a victim of bullying, but not to disclose any other details. Finally, we obtained consent from the child's teacher to participate in an interview. At the time consent was obtained from the teachers, they were told the name(s) of the child(ren) in their class who self-identified as a victim of bullying in the current school term. The research assistant also explained that consent and assent had been obtained from the parent and child to divulge this information, but none other, to the teacher.

We conducted semi-structured interviews with 13 teachers with respect to 17 children (10 teachers had one child in their class, two teachers had two children, and one had three). Five teachers had taught 
for fewer than three years, four had taught for over five years, and four had over 10 years of experience.

Three trained graduate students, with several years of social work experience, conducted interviews with the teachers, in a private room in the schools. The interviews with teachers who had one student in their class lasted 1 to $1 \frac{1}{2}$ hour-long, whereas the interviews with teachers who had more than one student lasted approximately 2 to $2 \frac{1 / 2}{2}$ hours. The research assistants audio recorded interviews; audio tapes were professionally transcribed. The interview began with the research assistant asking the teacher to talk about his or her response to hearing that the child self-identified as a victim of bullying. After the teacher spoke, the research assistant then asked other questions based on the interview schedule, including the teacher's understanding of bullying, whether the child had told the teacher about being bullied, responses to the child and to other bullying situations raised by the teacher, interactions with the child and, if applicable, with the parents, and perceptions of school support and the school's ability to respond to bullying. As we reviewed tapes and transcripts, we modified subsequent interviews (Tesch, 1990). For instance, based on the teachers' spontaneous responses, we added a question about their own experiences with bullying as children.

NVivo qualitative software was used to organize the data (Richards, 1999). In analyzing the interviews, we identified categories and themes (Merriam, 2002), and constant comparison led to groupings of similar concepts about the teachers' understanding of the children's victimization (Strauss \& Corbin, 1990). We identified consistent and contradictory themes that occurred. We took measures to ensure trustworthiness (Lincoln \& Guba, 1985). The researchers were very connected to this research through many years of clinical practice and research in this field and thus brought perspective and caution to the research. Through in-depth interviews and returning to teachers to verify developing themes, we addressed member checking.

\section{FINDINGS}

Awareness of Child's Identification as Bullied

Teachers were unaware that 10 of the 17 children were bullied, according 
to the children's self-identification on the questionnaire. Teachers were aware that seven students were bullied, all of whom told their teacher about at least one bullying incident. Of these seven children, teachers had worked with five students prior to the interviews in a variety of combinations to stop the bullying (e.g., victim, parents, and peers).

Defining Bullying

We asked teachers to define bullying, after which the interviewer read the following definition to ensure that the teachers were aware of the accepted definition of bullying (Olweus, 1989):

We say a student is bullied when another student or group of students say nasty and mean things to him/her or tease him/her a lot in a mean way. It is also bullying when a student is hit, kicked, threatened, locked inside a room and things like that. These things may happen often and it is hard for the student being bullied to defend him/herself. But it is not bullying when two students of about the same strength argue or fight. (n.p.)

The teachers all highlighted the existence of a power imbalance in bullying and the majority depicted bullying as intentional. All teachers included direct and indirect bullying behaviours in their understanding, although the teachers differed in how serious they considered the various forms. For instance, upon reflecting on the definition provided, a teacher who had not considered non-physical behaviours bullying shifted to include these behaviours, although she considered physical bullying more serious. In contrast to this perspective, other teachers expressed the view that non-physical bullying was as serious. Most teachers did not mention repetition as integral to bullying behavioural patterns.

Factors and Context in Determining and Responding to Bullying

Identifying that an incident is bullying and knowing how to intervene emerged as complex and confusing for teachers. Through analysis of the interviews, we found that several factors influenced how each teacher understood and responded to incidents. These factors included whether teachers viewed an incident as serious, whether they considered the victimized child responsible, whether the child matched their 
assumptions about victim characteristics and behaviours, and whether they described feeling empathy for the child. The nature of the school environment and organization support were further factors that influenced teachers' awareness and responses.

Whether the incident is considered serious. The meaning teachers ascribed to incidents seemed to influence whether they viewed an incident as normal or problematic. Non-physical victimization was at times deemed not serious and thus overlooked. One teacher, for instance, who believed that physical behaviours were more serious, was shocked that a student identified as a victim. The boy had complained about being called names, but because "he has friends and is liked" the teacher did not take his complaints seriously. The teacher became upset and questioned whether she could "take care of him and others if I don't see enough." It did not occur to another teacher that a girl "might be affected in her feelings or psychologically." This teacher who had seen boys repeatedly take the girl's possessions and call her names, said, "It is hard at this age to say whether they really want to hurt her when she is so adorable and pretty. I think boys say things to get her attention and show off, like a courting thing." It seems that because of her interpretation of the incident in this manner, the teacher did not intervene. In contrast, another teacher expressed dismay that children often normalized bullying and as a result did not discern when they themselves were bullied: "I'm in awe that when we introduce the concept of bully/victim, kids are shocked to find they are victims. To them this is normal behaviour."

Whether the child is considered responsible. Whether a child was seen as deserving of support seemed to depend partly on whether the teacher considered the child responsible for his or her victimization. One teacher reflected, "It's hard to know whether somebody constantly picked on is doing something to cause it," and another believed, "some children play the victim." One teacher believed the child in his class was indeed responsible and thus, despite recounting examples that illustrated the child's victimization by his peers, did not consider this child a victim.

Whether the student matches assumptions about victim characteristics and behaviours. A number of teachers who were surprised a student identified as bullied appeared to assume that victimized students would not seem 
well adjusted or would not be assertive. One teacher explained, "I've been assuming that it would affect your concentration and grades." Another teacher observed, "It never occurred to me that [child's name] would be bullied because she can stand up for herself." Other teachers were not surprised a child was bullied. Although previously unaware of the child's experiences, these teachers explained that the child displayed characteristics or behaviours they would expect to see in a victimized child. They added that the students in question had insecurities other children could exploit, such as their weight, or had unique qualities that "set them apart and made them vulnerable to bullying."

Whether the teacher feels empathy for the child who is bullied. Whether teachers felt compassion for a child seemed to influence their responses. For example, one teacher said that despite a boy's irritating behaviours, "It is not right that the other children treat him that way." This teacher worked both with the boy's peers to stop the bullying and with the boy to develop skills in responding to peers. Another teacher, who believed he understood a situation, did not agree with a girl's feeling that she was bullied through exclusion. In discussing the situation, the teacher focused on facts rather than the girl's expressed feelings. The teacher believed he had dealt with the situation effectively by speaking with the class about the inevitability of experiencing exclusion in life, and therefore was both surprised and perturbed to hear that the girl's mother later approached the principal with concerns about her child's exclusion. Some teachers did not appear to have compassion for a student who had identified as bullied. One teacher, for instance, said peers laughed at a boy but maintained that the boy "wants to be a victim." This teacher said the boy "never fully cried; it's always fake cries." He raised incidents when peers physically or verbally victimized the boy yet did not intervene because he thought the boy provoked others and therefore did not view him as a victim. This teacher said the boy's parents approached him with concerns about their son's victimization. He explained that he did not agree with their concerns and described having dismissed the parents' worries.

The nature of the school environment. Teachers commented on the influence of the school environment on their ability to identify and address bullying. One teacher, for instance, wondered if the physical 
bullying in her current school was masked, "because it's a more charged environment with much rougher kids, so you don't see it." A teacher in a school with a reputation of being nice was concerned that the myth of the nice school decreased teachers' and parents' vigilance. He believed the degree of bullying that went on "is just as much. It's a much more covert kind of bullying, but it still happens."

A number of the teachers felt pressured to teach the curriculum and respond to the numerous bullying-type incidents that occurred throughout the day. Most teachers expressed feeling that there was a lack of support and that they lacked the time and resources to address bullying adequately; they described feeling "exhausted," "scared," "helpless," or "fed up."

\section{Subjectivity}

Several teachers drew attention to the disparity between children's and their own opinions and perceptions. Some teachers thought their own views were objective, particularly in relation to verbal or indirect bullying. For instance, one teacher said, "When they get hit or pushed, there's not a lot of perception about that. But in the more subtle exclusion, sometimes the perception doesn't match up with the reality." Other teachers recognized a child's perceptions as valid. For example, one teacher told a group of girls who had been reported as bullying, "even if you don't mean to bully her, these actions are being interpreted." These teachers realized that although some forms of bullying might not seem serious to them, they were to the recipient. This realization is illustrated by a teacher who addressed the bullying, and validated the child's experiences despite having wondered whether the student "feels the bullying more strongly than it actually is." Other teachers questioned their own responses after they recognized that a child was more affected than they had imagined. Still others focused on determining the "objective reality," rather than on the child's subjectivity.

\section{Teacher Intervention}

Many teachers contrasted the existence of school policies dealing with direct bullying and the absence of guidelines addressing indirect 
bullying. In addition, the majority of the teachers stated that they did not know how to deal with indirect bullying. They explained that typically they sent children to the office for physical bullying, but as one teacher explained, "Bullying between girls can be hard to deal with in a disciplinary way, which is mostly what the vice-principal and principal do." The following example exemplifies this discrepancy. A teacher described an incident whereby a boy pulled a girl's pants down, which came to her attention when girls who witnessed the incident told the teacher the girl pulled her own pants down. When the truth emerged, the teacher sent the boy to the office and he was suspended. She did not, however, deal with the girls who witnessed and reported the incident because she was "afraid of fuelling gossip." This teacher was distressed and explained that she did not know how to deal with indirect bullying nor did she find the administration helpful.

The majority of the teachers reported that they did not receive training on bullying and expressed the desire for more training. An unanticipated effect of the research was the shift some teachers described in their views and actions. For example, after learning a child identified as bullied, when the research assistant contacted them to participate in an interview and informed the teachers the names of students who selfidentified as bullied, a few teachers reported monitoring students more closely.

Several teachers conveyed the need to intervene because of the children's developmental stage. As one teacher contended, "At this age they can't solve many disputes by themselves. They usually need someone to help guide them and that's what I try to do." Several teachers worked to foster a positive classroom atmosphere, whereby they facilitated discussions to deal with bullying and help students to problem solve, develop social skills, and build empathy. Respondents stated that they found it particularly taxing when they had not witnessed an incident. Many met with the victim, the bully, and witnesses to discern what actually occurred. Some tried to follow up with children individually and to monitor interactions; for instance one teacher joined students in the lunchroom to prevent conflict. 
Personal Experience

Almost all the teachers were bullied as children and several felt the effects persisted. One teacher believed s/he became a bully in response to having been bullied. A number of teachers described the bullying they had experienced as ongoing, serious, and scary. They portrayed themselves as being hit, threatened, excluded, and laughed at; many recalled having believed the names they were called, for example, that they were "poison" or "ugly." The teachers remembered feeling sad, nervous, afraid, and ashamed, and described the loss of self-esteem as especially painful. The majority did not tell anyone as a result of their shame or of having decided that the bullying "wasn't bad enough" to tell. Several teachers felt their experiences made them more sensitive and aware of the covert nature of bullying and of the need to watch for signs of bullying and to encourage students to disclose victimization.

\section{DISCUSSION}

In this study, we examined teachers' understanding of bullying and their views and responses to situations involving students who self-identified as victimized. Most respondents incorporated into their understanding of bullying the key components of the generally accepted bullying definition, with the exception of repetition, which very few of the teachers mentioned. With respect to their definitions, the teachers all referred to the power differential and most referred to the intent to hurt. Consistent with the findings of Siann and colleagues (1993), all the teachers stated that bullying could be direct or indirect. Because the effects of repetitious bullying, regardless of the severity of individual incidents, are well documented (Craig et al., 2000; Hazler et al., 2001), its glaring absence must not be ignored.

The finding that many teachers were unaware that their students were bullied is cause for concern, and is supported in the literature (Hanish \& Guerra, 2000; Newman, Murray, \& Lussier, 2001). Sorting out which behaviours constitute bullying is a difficult process and can contribute to a lack of intervention in bullying situations (Hazler, 1998; Hazler et al., 2001). The disparity between the definitions the teachers provided and how they depicted situations they discussed suggests that, although a clear definition is necessary for education, intervention, and 
research, it is not sufficient. The complexity in determining whether an incident constitutes bullying must be recognized. In this study, we identified the following factors that influenced teachers' identification and response to incidents: whether the incident was regarded as serious; whether the victimized child was considered responsible; whether the student matched assumptions about victim characteristics and behaviour; and whether the teacher described feeling empathy for the child who was bullied. In addition, the school environment and organizational support for the teachers influenced their awareness and responses.

Although all the teachers included indirect behaviours in their definitions, in response to situations they discussed about their students, teachers often considered physical bullying more serious and thus might not intervene in the indirect incidents. This pattern corresponds with findings that teachers perceive non-physical aggression, such as exclusion or verbal aggression, as less serious despite their inclusion in definitions (Astor et al., 1999; Smith et al., 2002). Moreover, several teachers presented details in the interview to indicate a child might be bullied. However, because of their assumptions about characteristics associated with victims, they were surprised that the students identified themselves as victims. Upon hearing that the students reported being victims, some teachers questioned their assumptions about victims.

The element of subjectivity in defining bullying can lead to differences in how teachers characterize incidents (Craig et al., 2000). Many teachers in this study doubted the children's subjective responses, particularly related to indirect bullying. At times teachers did not view incidents as bullying, although they depicted the child as feeling upset and bullied. Several teachers who described a child as "misperceiving" situations believed their own perceptions reflected reality. Such responses by teachers are significant because conclusions that adults draw can influence both their reactions and children's disclosure (Limper, 2000). Underestimating the harm caused by forms of bullying such as nonviolent victimization may lead to an inappropriate response, which can amount to further victimization (Astor, 1995). As Clarke and Kiselica (1997) have concluded, the effects of bullying carry into adulthood. "When school adults ignore, trivialize, or tolerate bullying 
incidents the victims internalize the implied message that the adults have discounted their worth as individuals, and they carry this message forward into adulthood" (p. 316).

When examining how teachers respond to children's experiences of bullying, the context must be considered. Teachers are under considerable pressure (Hazler, 1998), and report that student misbehaviour is a significant source of their stress (Boulton, 1997; Craig et al., 2000). Indeed, many teachers in this study described themselves as not capable of both covering the curriculum and dealing with the recurrent bullying-type incidents that occurred daily. The teachers often found it difficult to distinguish "normal" from bullying behaviours, and thus did not know how to respond. Moreover, they compared the existence of school policies for dealing with physical aggression with the lack of such guidelines for addressing non-physical bullying. The combination of teachers' lack of knowledge and their reported lack of systemic support must be considered to understand and address the relative neglect of indirect bullying.

Whether teachers felt empathy for a child seemed to influence how they depicted and responded to incidents. Among those teachers who did not judge specific incidents as serious or who thought the victim was responsible or misperceived the situation, it emerged that those who described feeling empathy for a child nevertheless tried to understand a child's experiences and factors that shaped his or her behaviours. This behaviour stands in contrast to other teachers who did not seem to have empathy for a child. For example, two teachers who described their students as crying "fake" tears each described significant problems with which these children struggled. However, these teachers did not try to comprehend the children's experiences or behaviours. Their descriptions correspond with the literature on children labeled "provocative victims" (Olweus, 1991, p. 424), who exhibit behaviours that both peers and adults find irritating (Nansel et al., 2001). Consequently, when such children report victimization, school personnel can tend to be unsympathetic (Astor, 1995). These findings correspond with research that identifies empathy as a key factor in how teachers characterize and respond to incidents and students and how they implement programs (Craig et al., 2000; Eslea \& Smith, 2000; Kallestad \& Olweus, 2003). 
Implications for Practice and Further Research

From the findings of this research we see implications for understanding and intervening in bullying behaviour in schools. Even when individuals are able to articulate a clear definition of bullying, other factors can influence how they characterize and respond to particular incidents. It is important for teachers to recognize that how they understand and respond to bullying can have an effect on their students. It would be beneficial to provide information to teachers on the factors that can influence individuals' decisions about what constitutes bullying and to help them recognize discrepancies between their espoused views and their reactions to bullying incidents.

Indirect bullying was particularly challenging for teachers to recognize and to know whether and how to intervene. The teachers often were unaware that a child felt bullied or did not consider a child's situation serious, even though the child or child's parent may have raised concerns with the teacher. It is necessary to emphasize the many forms of bullying and the long-term effects of indirect forms such as exclusion (Craig et al, 2000; Hazler et al., 2001). Consistent with other research (Siann et al., 1993), teachers neglected to consider repetition in most of their definitions, a finding that suggests teachers need help to understand the potentially devastating impact of repetitive behaviours, even those that appear minor (Craig et al., 2000).

Some teachers' assumptions about characteristics that victims would display (e.g., that they were not well adjusted), seemed to prevent them from recognizing victimized children who did not match their assumptions. This finding has important implications. There is a need to balance information on the characteristics that victimized children may exhibit with recognition that these characteristics need not be present in bullying situations. Further, focusing on individual characteristics of children who bully others or who are victimized can perpetuate and simplify the problem (O'Moore, 2000), can minimize awareness of factors such as the social context (Craig \& Pepler, 1997), and can obscure other factors considered central to bullying, such as the victimized child's experience of distress.

The finding that many teachers referred to subjectivity particularly with regards to indirect bullying corresponds with the literature (Ireland 
\& Ireland, 2000; Siann et al., 1993). Doubting a child's view may contribute to his or her lack of disclosure to teachers (Dawkins \& Hill, 1995; Mishna, 2004). Intertwined with subjectivity is empathy, which emerged as a theme that appeared to influence how teachers responded to the children who identified as bullied. Other research has similarly found an association between teachers' empathy for the bullied child and their responses (Craig et al., 2000; Kallestad \& Olweus, 2003). Teachers need assistance to become cognizant of their attitudes and of the possibility that a child's views may differ from their own and that a child's distress may be greater than an adult anticipates (Landau, Milich, Harris, \& Larson, 2001). Such understanding can increase a teacher's ability to recognize and intervene in bullying situations. Regardless of teachers' own views, they need help to listen to students' concerns and feelings (Craig et al., 2000). In addition, educators must protect children who are victimized but who might not recognize or feel they are bullied. A significant finding of this study was that the majority of teachers were themselves bullied as children. Many believed that their personal experiences as children influenced their reactions to their students. There is a paucity of research on teachers' past experiences with bullying and how these experiences may influence their definitions and responses to bullying. One study found an association between teachers who identified as bullied as a child with their responses and interventions (Kallestad \& Olweus, 2003), whereas findings of another study indicated that prior experience as a bully or victim did not significantly influence teachers' responses (Nicolaides et al., 2002). The prevalence of bullying, however, suggests that educators as well as other professionals may well have had experiences with bullying, either directly or indirectly. At the very least, this finding suggests that educators and other professionals must deal with their own feelings that incidents may evoke to respond effectively to bullying incidents (Gibbons, Lichtenberg, \& van Beusekom, 1994). A recommendation is to develop research with the purpose of further exploring links between past experience with victimization and teachers' responses and interventions to bullying incidents. Such research would be critical to developing effective interventions by teachers.

Teacher training is critical in identifying and responding to bullying 
(Boulton, 1997; Craig et al., 2000; Townsend-Wiggins, 2001) and teachers both require and want further training to increase their confidence and competence (Nicolaides et al., 2002). Most teachers in this study had not received training on bullying and expressed the desire for such training. An unanticipated effect of the research was the shift some teachers described in their views and actions, for instance being more watchful after learning that children identified as victims of bullying. Thus, the research process offers evidence of teachers' ability to examine and change their views and behaviours.

Teachers are in the front line in addressing bullying. Identifying and responding to bullying is complex and confusing. To impart more knowledge and training it is critical to understand the factors that influence how teachers understand and respond to bullying, and to recognize and acknowledge the context in which teachers function. Developing an awareness of the complexity of the phenomenon may lead to teachers becoming "more vigilant and responsive to bullying problems which, in turn, may give children more confidence to seek teachers' assistance when bullying occurs"' (Atlas \& Pepler, 1998, p. 94). Just as victimized students need empathy, so do teachers require understanding that they are in a very difficult position, whereby they must fulfill many roles including responding effectively to bullying. Many teachers in this study expressed concern about their lack of ability to deal fully with the bullying incidents due to pressure to cover the curriculum and to respond to the children and also conveyed a lack of systemic support, particularly related to indirect bullying.

\section{ACKNOWLEDGEMENTS}

This study was funded by a grant from the Social Sciences and Humanities Research Council of Canada. We acknowledge the support of the Toronto District School Board teachers and administrators, and the children and their parents; and research assistants Lynn Lavalee, Bonnie Miller, and Andrea Vick.

\section{REFERENCES}

Astor, R. A. (1995). School violence: A blueprint for elementary school interventions. Social Work in Education, 17(2), 101-115.

Astor, R. A., Meyer, H. A., \& Behre, W. J. (1999). Unowned places and times: Maps and interviews about violence in high schools. American 
Educational Research Journal, 36(1), 3-42.

Atlas, R. S., \& Pepler, D. J. (1998). Observations of bullying in the classroom. Journal of Educational Research, 92(2), 86-99.

Bernstein, J. Y., \& Watson, M. W. (1997). Children who are targets of bullying: A victim pattern. Journal of Interpersonal Violence, 12(4), 483-498.

Borg, M. G. (1998). The emotional reactions of school bullies and their victims. Educational Psychology, 18(4), 433-444.

Boulton, M. J. (1997). Teachers' views on bullying: Definitions, attitudes and ability to cope. British Journal of Educational Psychology, 67, 223-233.

Cairns, R. B., \& Cairns, B. D. (1991). Social cognition and social networks: A developmental perspective. In D. Pepler \& K. Rubin (Eds.), The development and treatment of childhood aggression (pp. 249-278). Hillsdale, NJ: Lawrence Erlbaum Associates.

Clarke, E. A., \& Kiselica, M. S. (1997). A systemic counselling approach to the problem of bullying. Elementary School Guidance $\mathcal{E}$ Counseling, 31, 310325.

Craig, W. M., Henderson, K., \& Murphy, J. G. (2000). Prospective teachers' attitudes toward bullying and victimization. School Psychology International, 21(1), 5-21.

Craig, W. M., \& Pepler, D. J. (1996). Understanding bullying at school: What can we do about it? In S. Miller, J. Brodine, \& T. Miller (Eds.), Safe by design: Planning for peaceful school communities (pp. 247-260). Seattle, WA: Committee for Children.

Craig, W. M., \& Pepler, D. J. (1997). Observations of bullying and victimization in the school yard. Canadian Journal of School Psychology, 13(2), 41-60.

Craig, W. M., Pepler, D., \& Atlas, R. (2000). Observations of bullying in the playground and in the classroom, School Psychology International, Special Bullies and Victims, 21(1), 22-36.

Cullingford, C., \& Morrison, J. (1995). Bullying as a formative influence: The relationship between the experience at school and criminality. British Educational Research Journal, 21(5), 547-560.

Dawkins, J. L., \& Hill, P. (1995). Bullying: Another form of abuse? Recent Advances in Paediatrics, 13, 103-122. 
Eslea, M. K., \& Smith, P. K. (2000). Pupil and parent attitudes towards bullying in primary schools. European Journal of Psychology of Education, 15(2), 207219.

Germain, C. B., \& Bloom, M. (1999). Human behavior in the social environment: An ecologicalm view (Second Edition). New York: Columbia University Press.

Gibbons, D., Lichtenberg, P., \& van Beusekom, J. (1994). Working with victims: Being empathic helpers. Clinical Social Work Journal, 22(2), 211-222.

Hanish, L. D., \& Guerra, N. G. (2000). Children who get victimized at school: What is known? What can be done? Professional School Counseling, 4(2), 113-119.

Hazler, R. (1998). Promoting personal investment in systemic approaches to school violence. Education, 119(2), 222-231.

Hazler, R.J., Carney, J.V., Green, S., Powell, R., \& Jolly, L.S. (1997). Areas of expert agreement on identification of school bullies and victims. School Psychology International, 18, 5-14.

Hazler, R. J., Miller, D. L., Carney, J. V., \& Green, S. (2001). Adult recognition of school bullying situations. Educational Research, 43(2), 133-146.

Ireland C. A., \& Ireland, J. L. (2000). Descriptive analysis of the nature and extent of bullying behaviour in a maximum-security prison. Aggressive Behaviour, 26(3), 213-223.

Kallestad, J. H., \& Olweus, D. (2003). Predicting teachers' and schools' implementation of the Olweus Bullying Prevention Program: A multilevel study. Prevention \& Treatment, 6(21) [Article A] Retrieved January 15, 2006, from http://content.apa.org/journals/pre/6/1/21.

Landau, S., Milich, R., Harris, M. J., \& Larson, S. E. (2001). “You really don't know how much it hurts": Children's and preservice teachers' reactions to childhood teasing. School Psychology Review, 30, 329-343.

Leff, S. S., Kupersmidt, J. B., Patterson, C. J., \& Power, T. J. (1999). Factors influencing teacher identification of peer bullies and victims. School Psychology Review, 28(3), 505-517.

Limper, R. (2000). Cooperation between parents, teachers, and school boards to prevent bullying in education: An overview of work done in the Netherlands. Aggressive Behavior, 26(1), 125-134. 
Lincoln, Y. S., \& Guba, E. (1985). Naturalistic inquiry. Beverly Hills, CA: Sage Publications.

Merriam, S. B. (2002). Qualitative research in practice: Examples for discussion and analysis. San Francisco: Jossey-Bass.

Mishna, F. (2004). A qualitative study of bullying from multiple perspectives. Children $\mathcal{E}$ Schools, 26(4), 234-247.

Nansel, T. R., Overpeck, M., Pilla, R. S., Ruan, W. J., Simons-Morton, B., \& Scheidt, P. (2001). Bullying behaviors among US youth: Prevalence and association with psychosocial adjustment. JAMA, 285(16), 2094-2100.

Newman, R. S., Murray, B., \& Lussier, C. (2001). Confrontation with aggressive peers at school: Students' reluctance to seek help from the teacher. Journal of Educational Psychology, 93(2), 398-410.

Nicolaides, S., Toda, Y., \& Smith, P. K. (2002). Knowledge and attitudes about school bullying in trainee teachers. British Journal of Educational Psychology, 72(1), 105-118.

Olweus, D. (1989). Questionnaire for students (Junior and senior versions). Unpublished manuscript.

Olweus, D. (1991). Bully/victim problems among school children: Basic facts and effects of a school based intervention program. In D. Pepler \& K. Rubin (Eds.), The development and treatment of childhood aggression (pp. 411-448). Hillsdale, NJ: Lawrence Erlbaum Associates.

Olweus, D. (1993). Bullying at school: What we know and what we can do. Oxford: Blackwell Publishers.

Olweus, D. (1994). Annotation: Bullying at school: Basic facts and effects of a school based intervention program. Journal of Child Psychology and Psychiatry and Allied Disciplines, 35(7), 1171-1190.

O'Moore, M. (2000). Critical issues for teacher training to counter bullying and victimisation in Ireland. Aggressive Behavior, 26, 99-111.

Owens, L., Shute, R., \& Slee, P. (2000). “Guess what I just heard!": Indirect aggression among teenage girls in Australia. Aggressive Behavior, 26(1), 67-83.

Pepler, D. J., Connolly, J., \& Craig, W. M. (1993). Safe School Questionnaire. Unpublished Manuscript. 
Prinstein, M. J., Boergers, J., \& Vernberg, E. M. (2001). Overt and relational aggression in adolescents: Social-psychological adjustment of aggressors and victims. Journal of Clinical Child Psychology, 30(4), 479491.

Richards, L. (1999). Using NVivo in qualitative research. Bundoora, Australia: Qualitative Solutions and Research Pty. Ltd.

Roberts, W. B. Jr., \& Morotti, A. A. (2000). The bully as victim: Understanding bully behaviors to increase the effectiveness of interventions in the bully-victim dyad. Professional School Counseling. Special Issue: School violence and counselors, 4(2), 148-155.

Schools Like Us Project Description (2001-02). Toronto: Toronto District School Board.

Siann, G., Callaghan, M., Lockhart, R., \& Rawson, L. (1993). Bullying: Teachers' views and school effects. Educational Studies, 19(3), 307-321.

Smith, P. K., \& Brain, P. (2000). Bullying in schools: Lessons from two decades of research. Aggressive Behavior, 26, 1-9.

Smith, P. K., Cowie, H., Olafsson, R. F., \& Liefooghe, A. P. D., (with Almeida, A., Araki, H., et al). (2002). Definitions of bullying: A Comparison of terms used, and age and gender differences in a fourteen-country international comparison. Child Development, 73(4), 1119-1133.

Strauss, A., \& Corbin J. (1990). Basics of qualitative research. Newbury Park, CA: Sage Publications.

Tesch, R. (1990). Qualitative research: Analysis types $\mathcal{E}$ software tools. New York: The Falmer Press.

Townsend-Wiggins, C. (2001). Teachers' perceptions of and interventions in episodes of bullying in schools. Dissertation Abstracts, 2001-2003/05.

Ziegler, S., \& Rosenstein-Manner, M. (1991). Bullying at school: Toronto in an international context. Toronto: Toronto Board of Education, Research Services. 